Article

\title{
Sustainable Social and Individual Implications of Telework: A New Insight into the Romanian Labor Market
}

\author{
Alina-Mihaela Dima ${ }^{1, *}$, Claudia-Elena Țuclea ${ }^{2, *}$, Diana-Maria Vrânceanu ${ }^{3}$ and Gabriela Țigu ${ }^{2}$ \\ 1 UNESCO Chair for Business Administration, Bucharest University of Economic Studies, 010731 Bucharest, \\ Romania \\ 2 Department of Tourism and Geography, Bucharest University of Economic Studies, 010404 Bucharest, \\ Romania \\ 3 Department of Marketing, Bucharest University of Economic Studies, 010404 Bucharest, Romania \\ * Correspondence: alina.dima@fabiz.ase.ro (A.-M.D.); claudia.tuclea@com.ase.ro (C.-E.T.)
}

Received: 31 May 2019; Accepted: 24 June 2019; Published: 26 June 2019

check for updates

\begin{abstract}
This research aims to evaluate the individual and social implications of telework, along with the foreseeable permanent result that could be generated. Consistent with this objective, a survey has been carried out on a sample of 1180 Romanian employees, on which a model has been developed, based on structural equation modelling. The model includes five latent variables, on the one hand targeting telework features and on the other hand, its possible effects on individuals and society. At an individual level, the study results emphasize that telework could contribute to a better work-life balance and could also help teleworkers to develop specific teleworking abilities. At a social level, telework could generate sustainable effects targeting the long-term management of the work force and providing solutions to potential problems at local community levels. The managerial implications of this study are directed toward the need to implement a series of sustainable human resource management strategies and efficient employee training and development programs. Moreover, organizations need to be more proactive in assuming corporate social responsibilities.
\end{abstract}

Keywords: telework; work-life balance; autonomy; teleworkers' abilities; social implications of telework

\section{Introduction}

While telework is a well-known and relatively established concept, in Romania it has been recognized only as of April 2018, when regulations have been issued specifically dedicated to telework. Whereas prior to these regulations, telework has been put into practice due to the real needs of companies and their employees, the pragmatic potential of telework has been ignored and the scarce academic research mostly focused on labor legal issues [1,2].

One could easily notice that the results of a large series of studies conducted over the past three decades are non-convergent, and sometimes even inconsistent, in terms of the effects of telework on employees [3-8]. Even though a significant number of studies show the benefits of telework for employees [9-12], there are also numerous studies that highlight the negative outcomes $[13,14]$.

The research done in this field can be categorized into 3 main categories: (a) the effects of telework on employees and their behavior as teleworkers, (b) the enterprises' attitude towards telework and the managerial challenges determined by telework, and (c) the social, organizational, and individual consequences of telework.

The present research aims to identify to what degree Romanian employees are familiar with the concept of telework, how they relate to the concept in terms of potential advantages and disadvantages, 
which are the objective conditions in which telework can be applied, and what is the willingness of the Romanian employees to accept such a work style. Additionally, this study attempts to diagnose the real situation regarding telework in Romanian companies. Moreover, the paramount objective of the present research is to verify whether the relationships existing in traditional work contexts are also preserved in telework contexts. Therefore, the link between work-life balance (WLB) and work satisfaction is revised, as well as the impact of autonomy on WLB. Additionally, connections between work autonomy and a series of abilities required to perform telework will be highlighted. The present study provides additional knowledge in the field via the conceptual model that targets the social implications of telework.

\section{Literature Review and Hypotheses}

Even though in Romania telework is in its initial development stages, in the advanced economies, the concept has been widely researched. However, researchers opinions have not always been convergent in terms of the effects telework has on employees, organizations, and societies overall.

Wojcak et al. [7] shows that the implementation of this new way to organize work activities brings new challenges for leadership, while Onken-Menke et al. [15] present evidence that flexible work schedules, including telework, increase the organization's attractiveness. Managers have to be trained in relation to the ways in which employees that work remotely could be efficiently managed, and new and effective methods to supervise remote workers are required [16].

Several studies additionally investigated the impact of telework on the environment and on the society as a whole. A special interest was generated by the relationship between telework and traffic jams and pollution generated by cars used to commute [17-19]. While Nakanishi [20] questions whether telework has a real contribution to save energy, Shabanpour et al. [21] shows that telework makes a contribution to the decrease of the total daily vehicle miles traveled and the total vehicle hours traveled, as well as the decline in greenhouse gas and particulate matter emissions.

These different results show that the effects of telework are not fully known, hence further investigation is required. In this context, our study aims to explore the effects of telework on Romanian employers and employees since the first regulations of telework have been issued. This research has not favored certain sectors of activity, but has investigated the perception of Romanian employees on telework in general.

\subsection{Telework, Work-Life Balance and Teleworkers' Skills}

A significant number of studies have revealed a strong connection between telework and personal-professional life balance in the case of individuals working from home. From the beginning, telework has been associated with a flexible work schedule, as numerous studies emphasize that flexibility in choosing the time and the place to work not only supports WLB [22-25] but also it is frequently a key factor when choosing an employer [24].

In traditional work contexts, there is a positive connection between WLB and work satisfaction level [26]. Consequently, Haar et al. [27] show a positive connection between WLB and professional satisfaction and a negative connection with anxiety and depression. Furthermore, every individual factor of WLB is an essential predictor of the professional satisfaction while professional satisfaction is, conversely, an important indicator of WLB [28].

In the present research, work satisfaction is defined by using the components identified by Zamfir [29], except for those concerning the presence of the employee inside of the enterprise. Consequently, determinant factors of satisfaction will be analyzed, such as: career opportunities, training opportunities, work conditions, and wage [30]. Accordingly, the present study suggests a first hypothesis:

H1. Telework satisfaction sources are positively related to work-life balance. 
According to other studies, an important issue related to telework is the autonomy concerning the performance of activities. For organizations that grant organizational support and autonomy to employees, telework is an efficient solution [31]. Furthermore, the connection between flexible work practices (FWP) and the organizational attachment is mediated by the autonomy that employees might think they have regarding the structure and control of how, when, and where they can work [15]. A benefit of telework for both employees and employers consists in the increase in the flexibility and autonomy of workers [32,33]. Specifically, teleworkers own the freedom to organize their own activities and to decide where and how to work $[6,34]$. Consequently, teleworkers feel that they have more control over their activities and more flexibility in scheduling both their regular working hours as well as extra working hours. This flexibility has been positively associated with WLB, specifically as a result of circumstance that family duties are no longer neglected as opposed to professional responsibilities $[35,36]$.

In this context, the present study puts forward a second hypothesis:

H2. The autonomy of teleworkers is positively related to work-life balance.

In order to achieve the WLB goals, teleworkers need to possess specific abilities, one of them being the ability to work and to solve problems independently [37]. McNaughton et al. [38] highlighted the need to train remote workers in digital skills and Golden [39] analyzes the effects of telework on burnout. Previously, a number of researchers have associated burnout with a set of negative results such as growing absenteeism, employees' high turnover, illnesses, decreasing work satisfaction, and low performances [40]. Hence, reducing burnout could become an objective where telework might make its own contribution [41]. Therefore, an important asset for teleworkers should be the ability to manage the signs of exhaustion, as well as the ability to manage distractions from work.

All these abilities have a positive impact on work satisfaction. The same positive impact is associated with work autonomy [42]. Lopes et al. [43] showed that an increased level of work autonomy is related with an increased well-being of the employees, including an increase of vitality, psychological flexibility, and self-accomplishment.

To conclude, it can be noted that both specific abilities of telework, as well as work autonomy, can generate the increase of work satisfaction for remote workers, which leads to the assumption of the third hypothesis:

H3. The autonomy of teleworkers is positively related to telework abilities.

\subsection{Social Implications of Telework}

The social implications of telework are scrutinized in numerous studies. A series of researchers have analyzed the impact of telework on women with children. Sullivan and Lewis [44] revealed that the main reason for which women accept to work remotely is to take care of their children. This issue has a major impact on WLB since it addresses the possibility to take care of family responsibilities, which is an important indicator of WLB [45]. WLB can also be achieved through better time management [46,47] and through stress reduction [48-50]. All these aspects can have a positive influence on employees' health $[47,51]$. In this way, the positive effects of telework on the individuals become real social implications, by increasing the number of employees and reducing health care costs (in Romania they are paid especially by national health insurance budget), to mention just these examples.

Various researchers investigated the durable effects of telework. Hynes [52] (p. 237) analyzes "the true social and environmental implications of individuals working from home". Also, Hynes [53] shows that, in Ireland, telework was an important incentive for shifting toward a sustainable transport model. Telework is perceived as having a positive impact on the environment and climate on account of its sustainable effects on energy consumption [54].

An additional social impact of telework is the decrease in unemployment among people with disabilities and other categories of vulnerable people [31]. The present research focuses on the decline 
in unemployment among inhabitants of rural areas, who, in Romania, represent a vulnerable social category [55].

Another highly researched consequence is the traffic decrease on the national roads $[31,56,57]$. Moreover, Chakrabarti [58] shows that telework (on average, at least once a week) is associated with a $15 \%$ increase of walking in the time span of a week.

In accordance with, first, the connection between telework and WLB, and second, the social consequences of telework, hypothesis $\mathrm{H} 4$ is submitted:

H4. WLB is positively related to the social sustainable implications of telework.

As it has been highlighted in the previous sections of this paper, the social consequences of telework are: professional opportunities for women with children, reducing unemployment in rural areas, and decreasing traffic on national roads. These positive effects of telework are constrained by the extent to which employees possess the requisite abilities. Upon analysis of the implementing stages of telework in a number of Japanese companies, Higa and Shin [59] showed that at an early stage, the right employees were selected for telework and additionally, they attended a special training for this new type of work context. Consequently, considering the social consequences of telework and the need for special abilities for such a work context, we suggest the following hypothesis:

H5. Telework abilities are positively related to the social sustainable implications of telework.

As a result of the provided hypotheses, the theoretical model that will be tested is presented in Figure 1.

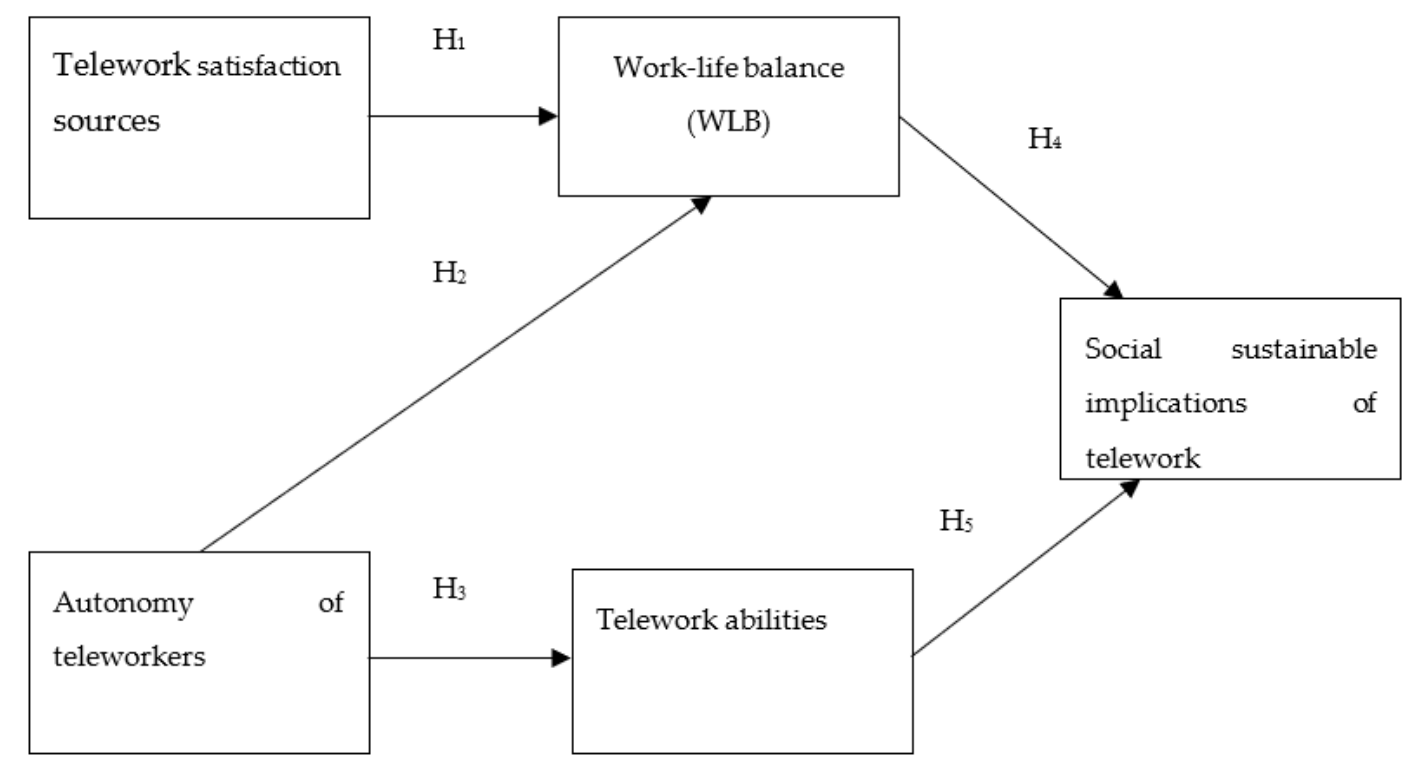

Figure 1. The conceptual model of telework implications.

\section{Research Methodology}

The research goal is to estimate the social implications and the sustainable effects that could be generated by telework. To achieve this goal, a national survey was carried out on a sample of 1180 employees. The statistical population for this study is represented by Romanian employees, the sampling variables being: age, gender, education, and type of employer. The sample structure is presented in Table 1.

Data was collected between 15 May and 4 June 2018 using field operators. They were trained on research purpose, objectives, and the criteria for selecting the sample. Data management was performed using Excel, whereas for data analysis a structural equation modelling (SEM) was designed 
by use of Warp PLS 5.0 software. Structural equation modelling aims to estimate the dependence relationships among a set of constructs that are incorporated into a model [60] (p. 796).

Table 1. The sample structure.

\begin{tabular}{|c|c|c|c|}
\hline \multicolumn{2}{|c|}{ Variables of the Sample } & \multirow{2}{*}{$\begin{array}{c}\text { Number of Employees } \\
191\end{array}$} & \multirow{2}{*}{$\begin{array}{c}\text { Percent } \\
16.2 \%\end{array}$} \\
\hline \multirow{5}{*}{ Age } & 18-25 years & & \\
\hline & 26-35 years & 270 & $22.9 \%$ \\
\hline & $36-45$ years & 261 & $22.1 \%$ \\
\hline & $46-55$ years & 241 & $20.4 \%$ \\
\hline & Over 55 years & 217 & $18.4 \%$ \\
\hline \multirow{2}{*}{ Gender } & Male & 593 & $50.3 \%$ \\
\hline & Female & 587 & $49.7 \%$ \\
\hline \multirow{4}{*}{ Education } & High school & 209 & $17.7 \%$ \\
\hline & Post-secondary school & 93 & $7.9 \%$ \\
\hline & University & 659 & $55.8 \%$ \\
\hline & Postgraduate studies & 219 & $18.6 \%$ \\
\hline \multirow{4}{*}{ Type of Employer } & Multinational company & 293 & $24.8 \%$ \\
\hline & Large Romanian company & 257 & $21.8 \%$ \\
\hline & $\begin{array}{l}\text { Small and medium-sized } \\
\text { Romanian company }\end{array}$ & 460 & $39.0 \%$ \\
\hline & Micro-firm & 170 & $14.4 \%$ \\
\hline \multicolumn{2}{|r|}{ Total } & 1180 & $100 \%$ \\
\hline
\end{tabular}

In the present study, a type of structural equation modelling, Path Least Square (PLS), was used. It involves defining latent variables (constructs) as aggregates of observed variables, while the structural model describes the relationships between these latent variables [61]. All the latent variables incorporated into the model were reflective. The model adequacy was assessed by evaluating the construct reliability and validity.

\subsection{Construct Reliability}

To validate the designed conceptual model, five latent variables were defined via items measured with a Likert scale (ranging from 1-Strongly disagree to 5-Strongly agree). As shown in Table 2, the composite variables are: satisfaction sources in telework (defined by four items), autonomy of teleworkers (defined by three items), abilities for telework (defined by three items), work-life balance (defined by four items), and social implications of telework (defined by three items).

To assess the internal consistency reliability of the constructs, composite reliability and Cronbach's Alpha coefficient were estimated. For PLS-SEM the composite reliability is more likely to be applied since Cronbach's Alpha coefficient presents some limitations [61]. The acceptance threshold for a good reliability is 0.7 [60]. In our research, the values for composite reliability are higher than 0.8 , showing a high level of reliability. This idea is also supported by the levels of Cronbach's Alpha coefficients that are higher than 0.7 [61], except for one latent variable whose value was very close to 0.7 , values above 0.5 being considered acceptable [62]. 
Table 2. Reliability for latent variables.

\begin{tabular}{|c|c|c|c|c|}
\hline Construct & Item & $\begin{array}{l}\text { Cronbach's } \\
\text { Alpha }\end{array}$ & $\begin{array}{l}\text { Composite } \\
\text { Reliability }\end{array}$ & AVE \\
\hline $\begin{array}{c}\text { Telework } \\
\text { satisfaction sources } \\
\text { (Source) }\end{array}$ & $\begin{array}{l}\text { Source } 1 \\
\begin{array}{c}\text { The career options of teleworkers are similar to those of the } \\
\text { employees that do not work remotely. } \\
\text { Source } 2\end{array} \\
\text { Teleworkers have the same training opportunities as employees } \\
\text { that work in offices. } \\
\text { Source } 3 \\
\text { The work conditions of teleworkers are similar to those of the } \\
\text { employees that work in offices (illuminating, heating, space). } \\
\text { Source } 4\end{array}$ & 0.71 & 0.821 & 0.535 \\
\hline $\begin{array}{l}\text { Autonomy of } \\
\text { teleworkers } \\
\text { (Auton) }\end{array}$ & $\begin{array}{c}\text { Auton } \mathbf{1} \\
\text { Teleworkers feel they have more control over their activities. } \\
\text { Auton } \mathbf{2} \\
\text { Teleworkers have more flexibility to arrange their working } \\
\text { schedule. } \\
\text { Auton } 3 \\
\text { Teleworkers have more flexibility in arranging the schedule that is } \\
\text { not work related. }\end{array}$ & 0.712 & 0.840 & 0.640 \\
\hline $\begin{array}{c}\text { Telework abilities } \\
\text { (Abil) }\end{array}$ & $\begin{array}{c}\text { Abil 1 } \\
\text { Teleworkers need to solve their problems independently. } \\
\text { Abil } 2 \\
\text { Teleworkers need digital literacy skills. } \\
\text { Abil } 3 \\
\text { Abil } 4 \\
\text { Teleworkers must be able to manage the burnout tendency. } \\
\text { Teleworkers must manage the work distractions. }\end{array}$ & 0.722 & 0.828 & 0.546 \\
\hline $\begin{array}{l}\text { Work-life balance } \\
\text { (Equil) }\end{array}$ & $\begin{array}{c}\text { Equil } 1 \\
\text { Teleworkers can face better the family responsibilities than office } \\
\text { employees. } \\
\text { Equil } 2 \\
\text { Equil } 3 \\
\text { Teleworkers can manage time more efficiently than office workers. } \\
\text { Teleworkers face less stress. } \\
\text { Equil } 4 \\
\text { Teleworkers deal with less work-related health issues. }\end{array}$ & 0.743 & 0.839 & 0.565 \\
\hline $\begin{array}{l}\text { Sustainable social } \\
\text { implications of } \\
\text { telework (Implic) }\end{array}$ & $\begin{array}{c}\text { Implic } 1 \\
\text { Telework offers professional opportunities to young mothers. } \\
\text { Implic } 2 \\
\text { Telework can reduce unemployment rate in the rural areas. } \\
\text { Implic } 3\end{array}$ & 0.694 & 0.831 & 0.621 \\
\hline
\end{tabular}

\subsection{Construct Validity}

In order to evaluate construct validity, convergent and discriminant validity should be assessed. The convergent validity signifies the extent to which a "scale correlates positively with other measures of the same construct" and all factors loadings should be higher than 0.5 (ideally higher than 0.7) and should be statistically significant [63] (p. 702). According to data shown in Table 3, for the items included into the latent variables, the factor loadings are statistically significant $(p<0.01)$ and exceed 0.7, except for two items that exceed 0.65 , which conveys a very good convergent validity. Another measure applied to assess this dimension of validity is the average variance extracted (AVE). This indicator evaluates how much of the variance of the observed variables is explained by the latent variables, the minimum acceptable level being 0.5 [61]. In Table 2, it can be seen that for all latent variables, the values for average variance extracted (AVE) are higher than 0.5 , with the latent variables explaining more than $50 \%$ of the variance of the observed variables. 
Table 3. Combined loadings and cross-loadings.

\begin{tabular}{cccccccc}
\hline Variab Item & Source & Auton & Abil & Equil & Impl & S.E. & $p$ Value \\
\hline Source 1 & $(0.764)$ & 0.096 & -0.035 & -0.073 & 0.026 & 0.027 & $<0.001$ \\
Source 2 & $(0.722)$ & -0.122 & -0.093 & 0.148 & 0.031 & 0.027 & $<0.001$ \\
Source 3 & $(0.712)$ & 0.015 & 0.055 & -0.076 & 0.037 & 0.027 & $<0.001$ \\
Source 4 & $(0.725)$ & 0.006 & 0.076 & 0.004 & -0.094 & 0.027 & $<0.001$ \\
Auton 1 & 0.016 & $(0.657)$ & -0.046 & 0.500 & -0.013 & 0.028 & $<0.001$ \\
Auton 2 & 0.008 & $(0.856)$ & 0.018 & -0.213 & -0.002 & 0.027 & $<0.001$ \\
Auton 3 & -0.020 & $(0.869)$ & 0.017 & -0.169 & 0.012 & 0.027 & $<0.001$ \\
Abil 1 & 0.029 & 0.066 & $(0.726)$ & -0.059 & 0.029 & 0.027 & $<0.001$ \\
Abil 2 & 0.023 & 0.044 & $(0.687)$ & -0.024 & -0.030 & 0.027 & $<0.001$ \\
Abil 3 & -0.021 & -0.124 & $(0.755)$ & 0.106 & -0.007 & 0.027 & $<0.001$ \\
Abil 4 & -0.027 & 0.020 & $(0.785)$ & -0.028 & 0.007 & 0.027 & $<0.001$ \\
Equil 1 & -0.031 & 0.201 & 0.099 & $(0.749)$ & 0.002 & 0.027 & $<0.001$ \\
Equil 2 & 0.012 & 0.193 & 0.024 & $(0.742)$ & 0.037 & 0.027 & $<0.001$ \\
Equil 3 & 0.006 & -0.072 & -0.079 & $(0.777)$ & 0.000 & 0.027 & $<0.001$ \\
Equil 4 & 0.013 & -0.322 & -0.041 & $(0.738)$ & -0.040 & 0.027 & $<0.001$ \\
Implic 1 & 0.013 & 0.154 & 0.078 & -0.120 & $(0.821)$ & 0.027 & $<0.001$ \\
Implic 2 & 0.028 & 0.007 & -0.113 & -0.019 & $(0.799)$ & 0.027 & $<0.001$ \\
Implic 3 & -0.045 & -0.178 & 0.035 & 0.154 & $(0.742)$ & 0.027 & $<0.001$ \\
\hline
\end{tabular}

Discriminant validity measures the distinctiveness of a construct from other constructs [60]. The loadings of an item with the associated latent variable should be higher than the cross-loadings with other latent variables [61]. As Table 3 shows, this condition is accomplished. By assessing the convergent and discriminant validity, we may conclude that the construct is valid.

\section{Results and Discussion}

To test the prior suggested hypotheses, a conceptual model was designed which evaluates the relationships between a series of latent variables, in terms of direction, strength, and statistical significance. The path coefficient ( $\beta$ ) evaluates the strength of the relationship between two variables, the sign of the path coefficient (positive or negative) indicates the direction of the relationship, and the $p$-value assesses the statistical significance of this relationship. In order to test the designed model and to determine the path coefficients between the variables of the model, a structural equation modelling procedure was performed, using WarpPLS 5.0 (ScriptWarp Systems, Laredo, TX, USA) software. The resulting model is presented in Figure 2.

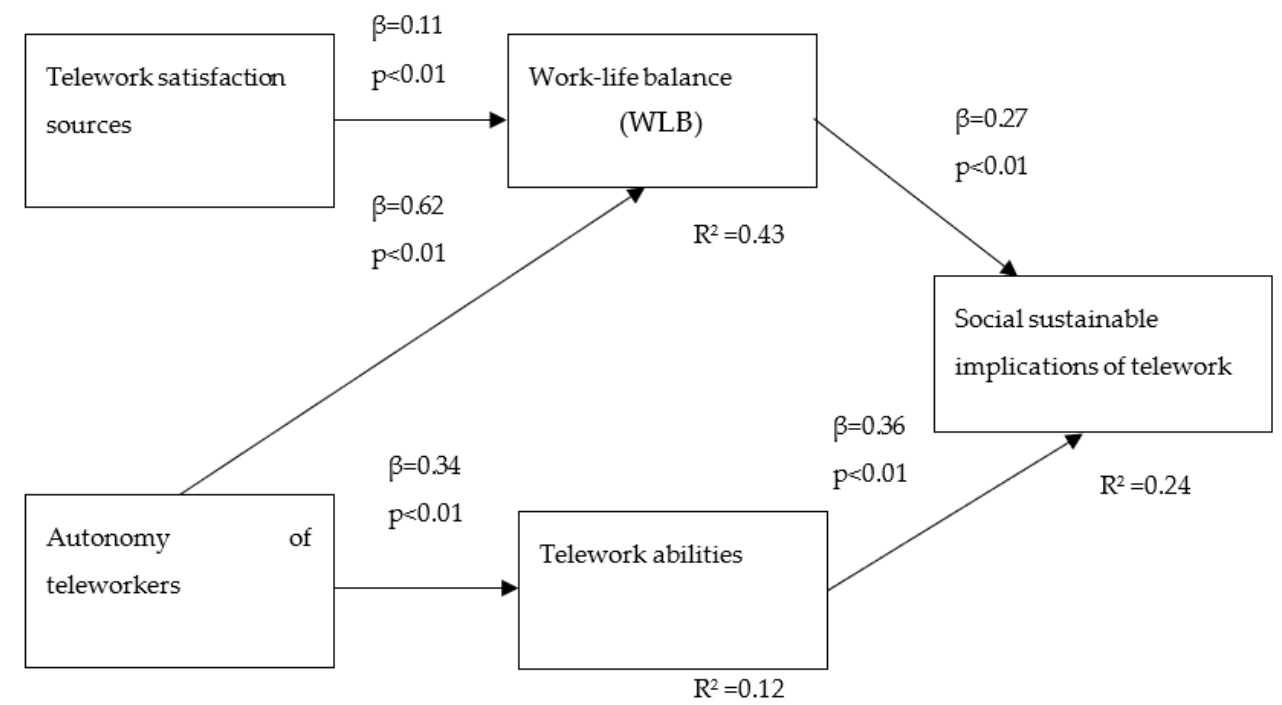

Figure 2. The tested model of telework implications. 
The probabilities (p) associated with path coefficients are lower than 0.01 , meaning that the relationships between the latent variables are statistically significant. Figure 2 further presents the coefficients of determination $R^{2}$, which indicate "the proportion of change in the dependent variable that is associated with changes in the independent variable" [64] (p. 296).

Figure 2 shows that the sources of satisfaction in telework have a significant effect on the work-life balance, with the path coefficient $\beta=0.11, p<0.01$, but the strength of the relationship is weak. Therefore, hypothesis $\mathrm{H} 1$ is accepted, which means that the type of satisfaction sources in telework do have an influence on the employees' work-life balance.

The autonomy of teleworkers has a positive influence on work-life balance, with a path coefficient of $\beta=0.62, p<0.01$. The autonomy of teleworkers and work-life balance are strongly positively related. Thus, the more employees perceive a greater autonomy associated with telework, the more they have a better work-life balance. Consequently, hypothesis $\mathrm{H} 2$ is supported by the results. The sources of satisfaction associated with telework and the autonomy of teleworkers contribute significantly to work-life balance, the coefficient of determination being $R^{2}=0.43$. Thus, the two variables explain $43 \%$ of the variation of work-life balance variable.

The autonomy of teleworkers has a positive influence, of moderate strength, over the telework abilities ( $\beta=0.34, p<0.01)$, thus hypothesis $\mathrm{H} 3$ is accepted. The greater autonomy teleworkers have in performing their professional and personal activities, the more they gain the required abilities for telework, both technical and non-technical. However, the low value of the coefficient of determination $\mathrm{R}^{2}=0.12$ shows that the autonomy in performing professional and personal activities only accounts for $12 \%$ of telework ability variation. This low value can be explained by the existence of other endogenous variables that could influence the acquiring of necessary abilities in telework.

Between work-life balance and sustainable social implications of telework there is a positive relationship of moderate strength, the value of the path coefficient being $\beta=0.27, p<0.01$. Consequently, a stable balance between professional and personal life associated with telework conveys positive social implications. The more telework balances the professional and personal life of an employee, the more the society has specific benefits such as: an increased rate of employment among young mothers, a decrease in unemployment rates in rural areas, and traffic decongestion on public roads. Therefore, hypothesis $\mathrm{H} 4$ is accepted.

Between telework abilities and sustainable social implications of telework there is a positive relationship of moderate strength ( $\beta=0.36, p<0.01)$, therefore $\mathrm{H} 5$ is accepted. The required technical and personal abilities for telework contribute to the personal development of the employees, in turn, this allows the involvement in work of categories of people that did not have the possibility to work within a traditional work frame before. Work-life balance and telework abilities account for $24 \%$ of the variation of sustainable social implications of telework. This result reveals an outstanding contribution of these variables to the positive effects that telework could generate.

\section{Conclusions, Managerial Implications, and Limitations of the Research}

The first research outcome shows a significant relationship between sources of telework satisfaction and work-life balance. According to our results, satisfaction sources, such as opportunities for career development and work conditions and remuneration, have a similar impact on WLB in telework as in traditional work activities. This conclusion aligns with other studies that focus on work satisfaction and WLB $[27,28]$. Moreover, the present study highlights the importance of this relationship in a telework context. A first implication at the organizational level is that managers can use the same motivational tools in teleworking contexts to increase work satisfaction and WLB. Another important implication is that teleworkers do not consider themselves a vulnerable socio-professional category. Quite the opposite, the flexible working schedule could become a competitive advantage for the organization. This perspective is highlighted by Maruyama et al. [24] when analyzing the importance of flexible schedule as a source of employees' satisfaction. 
Another conclusion underlines the assumption that the level of telework autonomy significantly influences WLB. The employee's control over their professional and personal activities has positive effects on time management, stress level, and other health issues. This perspective is consistent with Chung and Van der Horst's study [36] on the influence of flexible working hours on managing domestic issues. This result suggests that telework autonomy could increase the employees' attachment to the organization which consequently could decrease staff turnover and absenteeism, and also promotes the design of sustainable human resource management strategies. Such a strategy could aim, for example, to increase the capacity of enterprises to adapt to Industry 4.0 requirements by adopting digitalization of business in all its aspects [65].

The present research additionally highlights the relationship between the teleworkers' autonomy and their abilities. Thus, a high degree of autonomy determines employees to develop specific abilities in order to reduce their professional dependence on peers or managers. This perspective is addressed by another study [66] which correlates work autonomy-as a form of job resources-with perceived work abilities. An implication of this result is that teleworkers gain an intrinsic motivation to develop themselves professionally and personally. This could lead to an increase in the efficiency of staff training and development programs supported by the organization and could be a sustainable professional career strategy for the individual.

The final significant conclusion of the study concerns sustainable social implications of telework. Telework proves itself a sustainable work system that allows the access into the labor market of certain socio-professional categories that would otherwise have less employment opportunities (mothers with small children, people living in rural areas etc.). Following the directions set by other researchers [31,44,56,57], the model designed in this paper highlights that telework could generate sustainable social effects both in terms of human resources management (e.g., job opportunities for women with children, reducing unemployment in rural areas), as well as rendering other activities with social implications more efficient (e.g., reducing traffic on public roads). The issue of traffic on public roads has also been investigated from the point of view of time traffic [67], which can be considered a determinant of subjective well-being [68]. This suggests the possibility of biunivocal analysis of the relationship between the individual and social implications of telework. As a consequence, organizations could be more involved in corporate social responsibility activities and try to provide a long-term solution to the problems of the communities they belong to.

The results of the present research can be extrapolated cautiously to other countries, with telework implementation being influenced by various factors (legislative, cultural, technological, and demographic) specific to each country. For example, in Slovakia the employees perceive telework as an informal advantage with a potential positive impact on productivity and satisfaction [69]. Although the telework valence to create a better work-life balance seems quite universal, in France work-life balance is slightly perceived as a favorable factor for telework adoption [67]. However, telework becomes a valid option for large cities where the time spent on travel is high [67]. Corroborating these few examples with our research, a new hypothesis may arise: telework could be perceived more favorable in the Central and Eastern European countries than in Western Europe. This could be a new direction of research. The main limitation of the present study is that the model does not include all factors that could explain the social implications of telework. Therefore, future studies could include other organizational variables (e.g., attitudes of management towards telework) and individual variables (type of personality, socio-demographic variables, etc.).

Author Contributions: Conceptualization, C.-E.T.; methodology, D.-M.V.; formal analysis, C.-E.T. and D.-M.V.; investigation, C.-E.T. and G.T.; data curation, D.-M.V.; writing-original draft preparation, C.-E.T. and D.-M.V.; writing-review and editing, A.-M.D. and G.T.; supervision, A.-M.D. and G.T.; project administration, A.-M.D.; funding acquisition, A.-M.D.

Funding: The research published in this article has been supported by the Romanian government through the CERTRAN project-The Upgrade of the Research Capacity in Economics through Development of a Transdisciplinary Research Infrastructure. 
Conflicts of Interest: The authors declare no conflict of interest.

\section{References}

1. Popescu, R.R. Aspecte controversate cu privire la noua reglementare a telemuncii. Rev. Română Dreptul Muncii 2018, 3, 50-55.

2. Dimitriu, R. Munca în spațiul privat. Rev. Română Dreptul Muncii 2013, 9, 23-32.

3. DeSanctis, G. Attitudes toward telecommuting: Implications for work-at-home programmes. Inf. Manag. 1984, 7, 133-139. [CrossRef]

4. Haddon, L.; Lewis, A. The experience of teleworking: An annotated review. Int. J. Hum. Resour. Manag. 1994, 5, 193-223. [CrossRef]

5. Pinsonneault, A.; Boisvert, M. The impacts of telecommuting on organizations and individuals: A review of the literature. In Telecommuting and Virtual Offices: Issues and Opportunities; Johnson, N.J., Ed.; Idea Group Publishing: Hershey, PA, USA, 2001; pp. 163-185.

6. Gajendran, R.S.; Harrison, D.A. The Good, the Bad, and the Unknown About Telecommuting: Meta-Analysis of Psychological Mediators and Individual Consequences. J. Appl. Psychol. 2007, 92, 1524-1541. [CrossRef] [PubMed]

7. Wojcak, E.; Bajzikova, L.; Sajgalikova, H.; Polakova, M. How to Achieve Sustainable Efficiency with Teleworkers: Leadership Model in Telework. Proceedings of the 5th International Conference on Leadership, Technology, Innovation and Business Management. Procedia Soc. Behav. Sci. 2016, 229, 33-41. [CrossRef]

8. Sarbu, M. The role of telecommuting for work-family conflict among German employees. Res. Transp. Econ. 2018, 70, 37-51. [CrossRef]

9. Hill, E.J.; Ferris, M.; Märtinson, V. Does it matter where you work? A comparison of how three work venues (traditional office, virtual office, and home office) influence aspects of work and personal/family life. J. Vocat. Behav. 2003, 63, 220-241. [CrossRef]

10. Golden, T.D.; Veiga, J.F. The impact of extent of telecommuting on job satisfaction: Resolving inconsistent findings. J. Manag. 2005, 31, 301-318. [CrossRef]

11. Fonner, K.L.; Roloff, M.E. Why teleworkers are more satisfied with their jobs than are office-based workers: When less contact is beneficial. J. Appl. Commun. Res. 2010, 38, 336-361. [CrossRef]

12. Vega, R.P.; Anderson, A.J.; Kaplan, S.A. A within-Person Examination of the Effects of Telework. J. Bus. Psychol. 2015, 30, 313-323. [CrossRef]

13. Golden, T.D.; Veiga, J.F.; Dino, R.N. The Impact of Professional Isolation on Teleworker Job Performance and Turnover Intentions: Does Time Spent Teleworking, Interacting Face-to-Face, or Having Access to Communication-Enhancing Technology Matter? J. Appl. Psychol. 2008, 93, 1412-1421. [CrossRef] [PubMed]

14. Morganson, V.J.; Major, D.A.; Oborn, K.L.; Verive, J.M.; Heelan, M.P. Comparing telework locations and traditional work arrangements: Differences in work-life balance support, job satisfaction, and inclusion. J. Manag. Psychol. 2010, 25, 578-595. [CrossRef]

15. Onken-Menke, G.; Nüesch, S.; Kröll, C. Are you attracted? Do you remain? Meta-analytic evidence on flexible work practices. Bus. Res. 2018, 11, 239-277. [CrossRef]

16. Ansong, E.; Boateng, R. Organisational adoption of telecommuting: Evidence from a developing country. Electron. J. Inf. Sys. Dev. Ctries. 2018, 84, e12008. [CrossRef]

17. Nilles, J.M. Telecommuting and urban sprawl: Mitigator or inciter? Transportation 1991, 18, 411-432. [CrossRef]

18. Lund, J.R.; Mokhtarian, P.L. Telecommuting and residential location: Theory and implications for commute travel in monocentric metropolis. Transport. Res. Rec. 1994, 1463, 10-14.

19. Jaff, M.M.; Hamsa, A.A. Estimating commute-travel implications of telecommuting by female employees in Kuala Lumpur, Malaysia. J. Traffic Transp. Eng. 2018, 5, 148-155. [CrossRef]

20. Nakanishi, H. Does Telework Really Save Energy? Int. Manag. Rev. 2015, 11, 89-97.

21. Shabanpour, R.; Golshani, N.; Tayarani, M.; Auld, J.; Mohammadian, A. Analysis of telecommuting behavior and impacts on travel demand and the environment. Transport. Res. Part D Transp. Environ. 2018, 62, 563-576. [CrossRef] 
22. Duxbury, L.; Higgins, C.; Neufeld, D. TeleWork and the Balance between Work and Family: Is TeleWork Part of the Problem or Part of the Solution? In The Virtual Workplace; Igbaria, M., Tan, M., Eds.; Idea Group Publishing: Hersey, PA, USA, 1998; pp. 218-255.

23. Johnson, N.J. Case Study of the St. Paul Companies' Virtual Office for the Risk Control Division. In Telecommuting and Virtual offices: Issues and Opportunities; Johnson, N.J., Ed.; Idea Group Publishing: London, UK, 2001; pp. 148-161.

24. Maruyama, T.; Hopkinson, G.P.; James, P.W. A multivariate analysis of work-life balance outcomes from a large-scale telework programme. New Technol. Work Employ. 2009, 24, 76-88. [CrossRef]

25. Chung, H.; van der Lippe, T. Flexible Working, Work-Life Balance, and Gender Equality: Introduction. Soc. Indic. Res. 2018, 1-17. [CrossRef]

26. Malik, M.I.; Saleem, F.; Ahmad, M. Work-Life Balance and Job Satisfaction among Doctors in Pakistan. South Asian J. Manag. 2010, 17, 112-123.

27. Haar, J.M.; Russo, M.; Suñe, A.; Ollier-Malaterre, A. Outcomes of work-life balance on job satisfaction, life satisfaction and mental health: A study across seven cultures. J. Vocat. Behav. 2014, 85, 361-373. [CrossRef]

28. Kumari, L. Employees' Perception on Work Life Balance and its Relation with Job Satisfaction in Indian Public Sector Banks. Int. J. Eng. Manag. 2012, 2, 1-13.

29. Zamfir, C. Un Sociolog Despre Muncă şi Satisfacţie; Editura Politică: Bucureşti, România, 1980; pp. 15-40.

30. Emilian, R., (coord.). Managementul Resurselor Umane; Editura ASE: București, Romania, 2014; Available online: http://www.biblioteca-digitala.ase.ro/biblioteca/carte2.asp?id=48\&idb (accessed on 12 April 2019).

31. Gálvez, A.; Martínez, M.J.; Pérez, C. Telework and Work-Life Balance: Some Dimensions for Organisational Change. J. Workplace Rights 2012, 16, 273-297. [CrossRef]

32. Gregg, M. Work's Intimacy; Polity Press: Cambridge, UK, 2011; pp. $23-55$.

33. Tremblay, D.G.; Thomsin, L. Telework and Mobile Working: Analysis of Its Benefits and Drawbacks. Int. J. Work Innov. 2012, 1, 100-113. [CrossRef]

34. Pyöriä, P. Managing Telework: Risks, Fears and Rules. Manag. Res. Rev. 2011, 34, 386-399. [CrossRef]

35. Deery, M.; Jago, L. A framework for work-life balance practices: Addressing the needs of the tourism industry. Tour. Hosp. Res. 2009, 2, 97-108. [CrossRef]

36. Chung, H.; Van der Horst, M. Women's employment patterns after childbirth and the perceived access to and use of flexitime and teleworking. Hum. Relat. 2018, 71, 47-72. [CrossRef]

37. Omari, M.; Standen, P. Selection for telework. In Managing Telework: Perspectives from Human Resource Management and Work Psychology; Thompson Learning: New York, NY, USA, 2000; pp. 113-124.

38. McNaughton, D.; Rackensperger, T.; Dorn, D.; Wilson, N. Home is at work and work is at home: Telework and individuals who use augmentative and alternative communication. Work J. Prev. Assess. Rehabil. 2014, 48, 117-126.

39. Golden, D.T. Altering the Effects of Work and Family Conflict on Exhaustion: Telework during Traditional and Nontraditional Work Hours. J. Bus. Psychol. 2012, 27, 255-269. [CrossRef]

40. Carson, R.L.; Baumgartner, J.J.; Mathews, R.A.; Tsouloupas, C.N. Emotional exhaustion, absenteeism, and turnover intentions in childcare teachers: Examining the impact of physical activity behaviors. J. Health Psychol. 2010, 15, 905-914. [CrossRef] [PubMed]

41. Sardeshmukh, R.S.; Sharma, D.; Golden, D.T. Impact of telework on exhaustion and job engagement: A job demands and job resources model. New Technol. Work Employ. 2012, 27, 193-207. [CrossRef]

42. Blount, Y. Pondering the Fault Lines of Anywhere Working (Telework, Telecommuting): A Literature Review. Found. Trends Inf. Syst. 2015, 1, 163-276. [CrossRef]

43. Lopes, H.; Lagoa, S.; Calapez, T. Work autonomy, work pressure, and job satisfaction: An analysis of European Union countries. Econ. Labour Relat. Rev. 2014, 25, 306-326. [CrossRef]

44. Sullivan, C.; Lewis, S. Home-based telework, gender and the synchronization of work and family: Perspective of teleworkers and their co-residents. Gender Work Organ. 2001, 8, 123-145. [CrossRef]

45. Russo, M.; Shteigman, A.; Carmeli, A. Workplace and family support and work-life balance: Implications for individual psychological availability and energy at work. J. Posit. Psychol. 2016, 11, 173-188. [CrossRef]

46. Yu, X.; Meng, X.; Chen, Y.; Chen, Y.; Nguyen, B. Work-family conflict, organizational ambidexterity and new venture legitimacy in emerging economies. Technol. Forecast. Soc. Chang. 2018, 135, 229-240. [CrossRef] 
47. Hofmann, V.; Stokburger-Sauer, N.E. The impact of emotional labor on employees' work-life balance perception and commitment: A study in the hospitality industry. Int. J. Hosp. Manag. 2017, 65, 47-58. [CrossRef]

48. Cho, E.; Allen, T.D. The transnational family: A typology and implications for work family balance. Hum. Resour. Manag. Rev. 2019, 29, 76-86. [CrossRef]

49. Zhao, X.R.; Ghiselli, R. Why do you feel stressed in a "smile factory"? Hospitality job characteristics influence work-family conflict and job stress. Int. J. Contemp. Hosp. Manag. 2016, 28, 305-326. [CrossRef]

50. Razak, M.I.; Yusof, N.M.; Azidin, R.A.; Latif, M.M.; Ismail, I. The impact of work stress towards work life balance in Malaysia. Int. J. Econ. Commer. Manag. 2014, 2, 1-16.

51. Gamor, E.; Amissah, E.F.; Boakye, K. Work-family conflict among hotel employees in Sekondi-Takoradi Metropolis, Ghana. Tour. Manag. Perspect. 2014, 12, 1-8. [CrossRef]

52. Hynes, M. What's 'Smart' About Working from Home? Telework and the sustainable consumption of distance in Ireland. In Internet Research, Theory, and Practice: Perspectives from Ireland; Fowley, C., English, C., Thouësny, S., Eds.; Research-Publishing: Dublin, Ireland, 2013; pp. 225-243.

53. Hynes, M. Telework Isn't Working: A Policy Review. Policy Paper. Econ. Soc. Rev. 2014, 45, 579-602.

54. Van Lier, T.; de Witte, A.; Macharis, C. How worthwhile is teleworking from a sustainable mobility perspective? The case of Brussels capital region. Eur. J. Transp. Infrastruct. Res. 2014, 14, 244-267. [CrossRef]

55. Anghelache, C.; Anghel, M.G.; Marinescu, A.I. Analiza ratei de ocupare a populaţiei şi a costului lunar al forţei de muncă. Rev. Română Stat. Supl. 2018, 10, 3-16.

56. Wang, S.J.; Moriarty, P. Can new communication technology promote sustainable transport? Energy Procedia 2017, 142, 2132-2136. [CrossRef]

57. Hynes, M. Developing (tele) work? A multi-level sociotechnical perspective of telework in Ireland. Res. Transp. Econ. 2016, 57, 21-31. [CrossRef]

58. Chakrabarti, S. Does telecommuting promote sustainable travel and physical activity? J. Transp. Health 2018, 9, 19-33. [CrossRef]

59. Higa, K.; Shin, B. The Telework Experience in Japan. Commun. ACM 2003, 46, 233-242. [CrossRef]

60. Malhotra, N.K.; Nunan, D.; Birks, D.F. Marketing Research: An Applied Approach, 5th ed.; Pearson: New York, NY, USA, 2017; pp. 795-826.

61. Hair, J.F.; Hult, T.M.; Ringle, C.; Sarstedt, M. A Primer on Partial Least Squares Structural Equation Modeling (PLS-SEM); Sage: Los Angeles, CA, USA, 2017; pp. 95-115.

62. Hinton, P.R.; Brownlow, C.; McMurray, I.; Cozens, B. SPSS Explained; Routledge: London, UK, 2004; pp. 355-364.

63. Malhotra, N. Marketing Research. An Applied Orientation, 6th ed.; Pearson Prentice Hall: Upper Saddle River, NJ, USA, 2010; pp. 690-719.

64. Proctor, T. Essentials of Marketing Research, 4th ed.; Prentice Hall/Financial Times: Harlow, UK, 2005; pp. 296-312.

65. Trașcă, D.L.; Ștefan, G.M.; Sahlian, D.N.; Hoinaru, R.; Șerban-Oprescu, G.-L. Digitalization and business activity. The Struggle to Catch Up in CEE Countries. Sustainability 2019, 11, 2204. [CrossRef]

66. McGonagle, A.K.; Fisher, G.G.; Barnes-Farrell, J.L.; Grosch, J.W. Individual and work factors related to perceived work ability and labor force outcomes. J. Appl. Psychol. 2015, 100, 376-398. [CrossRef] [PubMed]

67. Aguilera, A.; Lethiais, V.; Rallet, A.; Proulhac, L. Home-based telework in France: Characteristics, barriers and perspectives. Transp Res. Part A Policy Pract. 2016, 92, 1-11. [CrossRef]

68. Serban-Oprescu, G.-L.; Dedu, S.; Serban-Oprescu, A.-T. An Integrative Approach to Assess Subjective Well-Being. A Case Study on Romanian University Students. Sustainability 2019, 11, 1639. [CrossRef]

69. Bajzikovaa, L.; Sajgalikovab, H.; Wojcakc, E.; Polakovad, M. How far is contract and employee telework implemented in SMEs and large enterprises? (Case of Slovakia). Procedia Soc. Behav. Sci. 2016, 235, 420-426. [CrossRef]

(C) 2019 by the authors. Licensee MDPI, Basel, Switzerland. This article is an open access article distributed under the terms and conditions of the Creative Commons Attribution (CC BY) license (http://creativecommons.org/licenses/by/4.0/). 